\title{
INTRODUCTION \\ Still Waiting for the Transformation
}

\author{
Carlo Fusaro and Amie Kreppel
}

The year 2011 is remembered as the year when Silvio Berlusconi's government fell and the Italian Second Republic entered its final stage, ${ }^{1}$ and the following year, 2012, has been remembered as the year dominated by technocrats in power. ${ }^{2}$ In contrast, 2013 has proven to be a year of incomplete transitions. The year has marked a period during which the Italian political and institutional system reached a nearly complete decisional stalemate, unable to move forward with political, institutional, or economic initiatives despite several erstwhile attempts.

The year 2013 was essentially bookended by two events that effectively symbolize this stalemate. The political year began with the unprecedented re-election-for the first time since the Constitution entered in force in 1948-of a standing president, the 88-year-old Giorgio Napolitano, despite the fact that he had announced in public more than once that he was not available for a second term. However, the legislature's inability to find an alternative left him little choice in the matter. The year ended with the Constitutional Court's decision to declare null and void the 2005 electoral law, substituting it with a significantly different one customized by the Court itself. ${ }^{3}$ These events signify an almost paralyzed polity. As the chapters of this volume make clear, these are just two of the most blatant signs of systemic political dysfunction.

Italy in 2013 was a country that continually seemed to be on the cusp of substantive reform and forward motion, but that never quite 
achieved it. The end result was, in many ways, a return to the muddling through behavior that characterized the end of the so-called First Republic (1993) - grand coalitions incapable of substantive decisionmaking, bold initiatives that languished in the legislature, failed and flailing foreign policy actions, and a continuing inability to tackle effectively the economic and social issues that face the country. Thus, for Italy, 2013 has been in many ways another year of transition following the fall of the First Republic. And although some of the political developments that took place in the waning months of the year may prove to be the foundation for future momentous changes, it is very likely that 2014 will prove to be a further continuation of the seemingly endless transitional period in Italy.

This introduction briefly summarizes the various examples of the Italian stalemate presented in the individual chapters of the current volume, while also pointing to some possible optimistic indicators for the future. In particular, we highlight what may be the first signs of an incipient stabilization of the financial and economic situation of the country and the elements that signal the timid blossoming of some improvement in the socio-political sector. Later we briefly discuss the potential for change prompted by political developments that occurred in the fall and in the last months of 2013.

\section{An Apparently Moribund Polity}

The Italian decline certainly did not start in $2013 .{ }^{4}$ One could arguably claim that the last sign of a strong and bold decision, as well as of a clear sense of economic direction, was the adoption and implementation of the financial policies meant to allow Italy to be part of the Eurozone from its inception (during the 1996-2001 parliamentary term). Thereafter, the political leaders on both the right and the left have let the country drift along, largely ignoring broadly recognized endemic political, social, and economic problems. During the admittedly brief window of opportunity before the global economic upheaval began in 2008, Italy never truly attempted to address the structural weaknesses in its economy or take advantage of the financial leverage ensured by many years of low interest rates (the most relevant and positive effect of the euro). Thus, when the Great Recession took hold, and in particular when it shifted from a more narrowly defined financial upheaval to a major economic crisis, Italy's monstrous public debt became a burden that the Berlusconi Cabinet proved unable to manage. This prompted the establishment of an emergency cabinet made of, and led by, technocrats. 
It is clear that the Italian political and party systems were already undergoing major difficulties, as demonstrated by the necessity of the technocratic Monti Cabinet and the inability of Parliament to introduce adequate political and institutional (electoral and constitutional) changes meant to improve the basic functionality of the system well before the start of 2013. However, the 24-25 February 2013 parliamentary elections proved to be a tsunami that left Italy in a state of political paralysis. This was in large part due to the outstanding result of the Movimento Cinque Stelle (M5S, Five Star Movement) led by former comedian Beppe Grillo. The M5S was able to obtain roughly the same vote share as the main traditional parties, Partito Democratico (PD, Democratic Party) and Popolo della Libertà (PdL, People of Freedom), despite it being the first time that the M5S had competed at the national level (see Chiaramonte, this volume). The success of the M5S gave birth to a tri-polar political system that supplanted the bipolar one established in 1994 and deprived the PD leader (Luigi Bersani) of his chance to form a cabinet. The leftist coalition, with the PD at the helm, did win the Chamber of Deputies with a solid majority, thanks to the electoral law in force at the time (passed by the third Berlusconi Cabinet in 2005), which awarded a substantial "bonus" to the largest party. However, the coalition fell significantly short of acquiring a similar majority in the Senate, which must provide a vote of confidence on exactly the same footing as the lower chamber. The surprising national success of the M5S need not have been insurmountably catastrophic for the functioning of the government; however, the unwillingness of the M5S to support any cabinet built around either or both of the major center-right and center-left parties guaranteed a largely dysfunctional coalition between the PD and PdL. The untenable character of a grand coalition between the two parties was evident from the outset, given the broad ideological and policy differences between them (see Ceron and Curini, this volume).

As a whole, 2013 serves as convincing, spectacular, and thoroughly disconcerting evidence that the Italian polity had become incapable of doing more than barely surviving while waiting for some obscure and unpredictable future change-one that might be difficult to foresee but would nonetheless be unavoidable and likely to be welcomed. Even the most minimal vital functions of a political and institutional system have proven difficult to ensure in the Italian context. It was not only the formation of the first cabinet of the 2013-2018 parliamentary term that loomed immediately as a daunting task; ${ }^{5}$ in addition, the two chambers seemed initially unable even to elect a new president of the Republic. The largest political party, the PD, suffered a resounding defeat, demonstrating itself incapable of delivering a candidate able to win the full 
support of even its own party members (generally considered a minimum requirement for a parliamentary party to be classified as such).

A striking illustration of a political system on the verge of a breakdown was the procession of humiliated party leaders making their way to the Quirinal Palace in order to ask-or rather beg-the outgoing president to accept re-election as the only solution to the stalemate. It is no surprise that Napolitano agreed to serve, although only "as long as suggested by the situation and as long as my strength will allow." The newly re-elected president delivered a speech to the chambers that was effectively a reprimand meant to castigate the impotency of an entire political class and to request urgent reforms along the lines agreed to previously by those same leaders without any successful results in the 2008-2013 parliamentary term. ${ }^{6}$ He received many rounds of thunderous applause, but 10 ten months later still no tangible results (see Clementi, this volume).

In fact, although everyone gave the usual lip service to President Napolitano's requests and vowed to pursue the announced reforms, at year's end there was nothing tangible to show for it. Even more disturbingly, Enrico Letta's Cabinet, which was supposed to push for electoral and constitutional changes and included a specific minister (Gaetano Quagliariello) charged with the oversight of constitutional reforms, was forced to abandon most of its bold efforts after just a few months. This unfortunate result came despite all the announcements and commitments made by the political elite and the fairly rapid completion of a comprehensive and well-engineered draft set of constitutional amendments by a special commission of "wisemen" (and women) drawn from various fields. In early December, the proposal for a special procedure for constitutional reforms within 18 months was abandoned (although it had been approved two times by the Chamber and once by the Senate). ${ }^{7}$ Efforts at institutional (and other) reforms fell victim to the political consequences of Berlusconi's conviction for tax fraud and his subsequent ouster from Parliament. By this juncture, all sense of urgency regarding constitutional reform had already been lost, despite the broad agreement that some type of reform was necessary. The result was that the entire process of constitutional reform was at risk and appeared once again to be on a road to nowhere (see Lanzalaco, this volume).

The inability of the political system to achieve substantive reforms to increase its stability and functionality was in part responsible for the December 2013 decision by the Constitutional Court to strike down the 2005 electoral law. Aside from any evaluation of the content, merits, and procedural intricacies of this decision, which were bound to make it profoundly controversial, ${ }^{8}$ the very fact of its adoption effectively 
serves as the tombstone on a moribund polity. It is a sort of solemn seal certifying the impotence of political institutions that are unable to provide even the most basic precondition for their minimal functioning - a suitable and constitutionally viable electoral law.

Nor was the Letta Cabinet, despite its good intentions and admirable goals, significantly more successful in other policy areas. Subject to all the constraints of a composite and internally conflicted majority (albeit the only one allowed by the uncooperative tripolar Parliament born from the February elections), and limited by permanent budgetary headaches, the Letta government in both versions (with and without Berlusconi's side) achieved only small incremental changes within the context of the badly needed structural reforms meant to relaunch Italy's economic growth.

Further evidence of the inability of the Letta government(s) to achieve their policy goals can be seen in the remarkably small number of substantive laws that were successfully passed. In 2013, just 25 significant laws, of which the Letta government initiated 21, were adopted. ${ }^{9}$ Even these paltry numbers substantially exaggerate the actual efficacy of the Letta governments, as only 8 out of the 21 (38 percent) represent more than converted law decrees. A closer examination of those eight laws reveals an even more disconcerting picture: one pertained to the Anti-Mafia Parliamentary Commission, which is re-voted at every legislature; one was the ratification of the Istanbul Convention (the Council of Europe Convention on Preventing and Combating Violence against Women and Domestic Violence); two were mandatory European laws merely meant to implement EU directives; and the remaining four were budgetary laws (and therefore also mandatory), including the annual stability law. Thus, it could be argued that not one single significant non-mandatory new law was adopted in 2013 by the Letta government.

During the same period, the economic situation of the country continued to decline. Industrial production fell by 3 percent and the GNP by 1.9 percent, while unemployment rose to 12.9 percent and youth unemployment (excluding students) rose to about 40 percent. ${ }^{10}$ The credit spread went down from 260 to around 200, but the ratings of the major agencies (Moody's, Fitch, S\&P) did not change, remaining at their lowest historical levels. At the same time, the national debt rose to 132.6 percent of the annual GDP, up from 127 percent at the end of 2012, and global taxation fell from 44 percent to 43.8 percent, a diminutive -0.2 percent of the GDP. ${ }^{11}$

Of course, little of this can be regarded as directly the Letta Cabinet's responsibility. Many of the problems within the political and economic system in 2013 were inherited and result from both a history 
of political intractability and the nearly insurmountable obstacle generated by the results of the 2013 legislative elections. However, these data underscore the existence of a general trend that has been all but significantly upended in the course of its tenure. ${ }^{12}$

At the same time, in the midst of the economic tribulations and the political stagnation, 2013 witnessed an Italian government all but incapable of effectively managing its foreign policy or of exercising legitimate control over Italy's domestic political actors. Both the final months of the Monti government and the short-lived Letta governments were tainted by major international embarrassments. Of particular note was the Italy-India dispute concerning the prosecution of two Italian marines accused of having killed two harmless Indian fishermen by mistake, as well as the unfortunate expulsion from Italy of the wife and daughter of the dissident Kazakh Mukhtar Ablyazov, who were flown back to Kazakhstan at the request of the Kazakh ambassador in Rome (see Bellandi, this volume). An example of the absence of effective oversight can be found in the embarrassing behavior of the minister of justice, Annamaria Cancellieri, also a former prefect and minister of interior in the Monti Cabinet. Although highly esteemed by the president of the Republic and in possession of substantial government experience, Minister Cancellieri was revealed to have engaged in, if not illegal, at least highly dubious telephone conversations concerning the custody ordered by the prosecutors of the daughter of a very controversial insurance and financial tycoon, Salvatore Ligresti, who was under investigation.

A final example of political incapacity can be found in political discourse concerning the issue of the suppression of a disputed property tax (IMU), which was requested by the PdL as a precondition for supporting the first Letta Cabinet, and the parallel issue of the conviction of Berlusconi (the undisputed leader of the PdL) and its legal effects (as outlined in the chronology, this volume). The saga over Berlusconi's legal concerns lasted from June through October, day after day, constantly threatening the stability of the Letta Cabinet. ${ }^{13}$ Even after its resolution and the subsequent exit of Berlusconi from Parliament and the PdL from the government, the conflict over the IMU continued. This occurred despite the fact that the original motivation for the compromise (the PdL-PD governing alliance) was no longer relevant since the government had already lost Berlusconi's support.

Indeed, the IMU story has proved particularly paradoxical: on the one hand, it will remain as the only accomplishment of Letta's 10 months in office that might be remembered; on the other hand, the way that the abolishment of this property tax was finally ensured at the end of a painstaking process seemed to leave everyone unhappy. 
Those who had opposed the measure were obviously displeased. Those who had supported it soon realized that it was limited to the house one lives in and did not apply to any additional properties. Taxes would still be owed on those properties and would actually be higher than before. Indeed, even the single property owners of 2,800 out of 8,100 municipalities had to pay some extra IMU in January 2014 because of previous miscalculations. And all this in order to fulfill a political commitment toward an ally that, in the meantime, had become a fierce opposition party. This was a true masterpiece of governmental mismanagement that left everyone dissatisfied and the treasury poorer.

\section{And Yet It Moves}

In spite of the multiple signs of systemic political paralysis noted above, there was some forward motion in the Italian political sphere, ${ }^{14}$ albeit often through the intrinsically flawed technique of two steps forward and one step back. In this perspective, the year has not been entirely wasted. The Letta government has achieved some minor accomplishments, while other events that took place were managed with at least a mixed outcome. Not least among the achievements of the Letta government was the appointment of Italy's first black Cabinet member, Cécile Kyenge, as minister of integration. Kyenge, long an advocate of reforming the restrictive citizenship laws in place since 1992, immediately reignited the debate over reform and pushed the legislature to work through the numerous existing proposals for reform. Unfortunately, the breadth of the ideological distance between the Letta government's coalition partners over the issues of citizenship and migration law reform effectively blocked substantive forward motion on new legislation. Despite this, the presence of Kyenge in the government was an important first step in fully integrating legal immigrants into the political as well as the social sphere, and it helped to promote the cause of legal immigrants and their children seeking citizenship status (see Bianchi, this volume). ${ }^{15}$

Some substantial progress was also made in the arena of gender equality during 2013, although not all of the progress can be said to result from deliberate government actions. The February legislative elections resulted in the highest number of women ever sent to Parliament, with nearly one-third of MPs (31 percent) being women, one of the highest rates in Europe. The election of Laura Boldrini as president of the Chamber of Deputies further increased the influence of women in the political sphere and helped to ensure that gender equality 
and the fight against domestic violence would be priorities. Indeed, in June, Parliament's adoption of the Istanbul Convention was followed by a successfully converted decree law partially focused on reducing violence against women. Beyond the political realm, 2013 was also, perhaps surprisingly, a good year for female employment. In contrast to the precipitous decline in employment levels among men, the number of women with full-time employment actually increased. Although this may not be a positive omen for the economy as a whole, it signaled further improvement to the status of women in Italy (see Donà, this volume).

The banking sector is another arena in which the Italian political sphere managed better than might be expected, given the broader political and economic conditions. Despite the fact that it suffered some significant setbacks, including the well-publicized need for the government to intervene with a bailout (in the form of a loan) for the Monte dei Paschi di Siena (MPS) and the subsequent difficulties of several smaller banks, the banking sector as a whole weathered the Eurozone crisis comparatively well. Although there are clearly elements within this sector in need of reform (e.g., the continuing influence of largely unregulated foundations), the underlying structure performed substantially better than several other Eurozone countries, allowing Italy to avoid a scenario in which a sovereign debt crisis escalated into a widespread banking crisis (see Quaglia, this volume).

In addition, despite the deadlock created in the national legislature as a result of the rise of the M5S, party politics at the local level appeared for the most part to able to manage partisan and political upheavals with few problems. The electoral rules governing the different levels of local and regional governments and the timing of these second-tier elections substantially impacted the extent to which they followed the national model in terms of outcomes and the shape of partisan coalitions, although generally speaking the PD came out ahead at the regional and local levels (with the unsurprising exception of Lombardy). Indeed, in strong contrast to the national level, regional and local elections maintained a basically bipolar character, which greatly facilitated the organization of government. This initially surprising outcome, given the tendency for new and fringe parties to perform better at the local and regional levels, was due at least in part to the variation in electoral rules that govern these elections. Even more, it was likely due to the direct election of both mayors and regional presidents, which proved to generate a decisive bipolarizing effect. Regardless of the explanation, given the dysfunction at the national level, it is worth highlighting that the regional form of government still seems 
to function in spite of all campaigns against the costs of politics (see Massetti and Sandri, this volume).

\section{Political Crisis Calls for Political Answers}

Eventually, the Italian party system began to react to the clear political stalemate, attempting to cope with both the outcome of the February 2013 elections and the later developments discussed above. These electoral and judicial tsunamis resulted in unavoidable pressure for some kind of reform.

On the center-right, this reform began as an outcome of internal disputes and decisions over continued participation in the government coalition. Letta's majority started to change in October when Angelino Alfano, the deputy prime minister and former PdL leader appointed by Berlusconi himself, announced he would keep supporting the Cabinet even despite Berlusconi's decision (on 1 October) not to do so. Alfano later seceded from the convicted tycoon's party with part of the PdL parliamentary delegation after the decision by the Senate to oust Berlusconi from his parliamentary seat (on 27 November 2013) and the refusal by the PdL to vote in favor of the 2014 budgetary law (the day before). As many as 32 senators and 29 deputies followed Alfano, giving birth to the new party, the Nuovo Centrodestra (NCD, New CenterRight). Berlusconi had already decided a couple of months earlier to relaunch his personal party, Forza Italia, which was first established in 1994. This action was meant to rally his most faithful supporters during his difficult legal battles (see Paolucci, volume).

On the left of the political spectrum, after former PD leader Bersani's double defeat (parliamentary elections, failure to deliver a successful presidential candidate), Guglielmo Epifani, a former trade union leader, became the caretaker secretary of the party, in charge of organizing its November convention. It should be remembered that according to the statute of the PD, a convention involves an open vote on a set of candidates previously selected by the party's members among themselves. The three or four top candidates within the party are submitted for approval to voters at large. Anyone (even minors over 16 and resident immigrants) is allowed to vote as long as he or she commits to support the party program and voluntarily contributes to the cost of the primary, paying as little as 2 euros (about US\$3).

In the aftermath of the disastrous February parliamentary elections, it had become apparent that a comeback by Florence's mayor, Matteo Renzi, who had been defeated a year earlier by Bersani in the November 2012 primary, would make him the most credible 
candidate to be the new PD leader, in spite of-and possibly even thanks to-the strong opposition of a large part of the most conservative leadership within the party. It is worth noting that Renzi, who is not an MP, for several years had depicted himself as the one who would have "made scrap out of the old party guard." By doing so, he was skillfully able to meet the expectations of large constituencies both within and outside of the PD. This was significant, as the PD, a party established in 2007, has proven incapable of creating a truly homogeneous leadership group. Instead, it has remained internally divided between the various factions that joined together to form the party to begin with.

As a consequence of the additional set of individual flaws and failures demonstrated by all those who led the party during and after the 2013 electoral campaign, it was of little surprise that Renzi prevailed initially among the party's members ${ }^{16}$ and later obtained a truly resounding victory in the PD's open elections on 8 December 2013, in which almost 3 million voters took part. As the outcome demonstrates, Renzi enjoys, at least for the moment, the support of more than two out of three voters who participated in the primary. ${ }^{17}$

The next day, even before having been formally elected, Renzi announced a team composed of seven women and five men, whose average age was 35 (Renzi himself was at the time 38), to help him lead the PD. At that point, after the convention, he was able to count on the support of a solid majority within the General Assembly and among the leadership of the party. Furthermore, as secretary of the PD he had become, by statute, the party's candidate for the office of prime minister during the next election, whenever that might be. ${ }^{18}$

From the first day in office, Renzi made a constant and relentless effort to meet the expectations he himself had raised for years: to be a leader who is able to act swiftly, conveying a sense of great urgency in relation to the need to cope with Italy's problematic political, financial, and economic overall situation, and at the same time to be seen as an "outsider" when compared to the traditional party leadership within and outside of the PD. As an acting mayor and a pragmatic leader focused on tangible accomplishments, Renzi was especially well-placed to take on this position. Perhaps more importantly, he had never been involved in Roman politicking.

In his speech to the party leadership on 15 December 2013, Renzi called on Letta and his Cabinet to engage in more forceful and dynamic action. At the same time, he announced that he would pursue an agreement with both or even only one of the two main opposition parties (M5S and Forza Italia) to allow Parliament to pass a new electoral law immediately after the traditional end-of-year parliamentary recess. It 
should be noted that the inability to change the existing and hypercriticized electoral law is considered by most to be both the cause and the effect of Italy's party system defects. Most recently, it also served as the justification employed by the Constitutional Court in striking down the 2005 electoral law. ${ }^{19}$

Although Grillo disdainfully refused to cooperate within seconds (via tweet), Berlusconi soon let it be known that he was both interested and available. The former prime minister's situation as a "lame duck leader" ousted from Parliament, at least for the time being, made him much more prone to compromise than might otherwise have been the case. This move shook the slim majority that supported Letta's Cabinet, as it appeared to be not only a way to accomplish a mandate indirectly assigned by the Court and long encouraged by the president of the Republic, but also a potential short cut toward new (early) elections. However, the paradox of Italian politics in the present legislative term (2013-2018, at least according to the usual term) is that, on the one hand, everyone pays lip service to the obvious fact that a new electoral law is very badly needed, but, on the other hand, relevant parliamentary forces that might suffer electorally as a result ${ }^{20}$ are more than happy to postpone any electoral reform that would make new elections a suitable solution to Italy's stalemate. The point is that some of these forces are necessary components of the majority on which Letta's and any other cabinet has to be based (if one considers that two of the major parties, Forza Italia and M5S, are not willing to support any cabinet). A striking example is Alfano and his newly formed party: the NCD cannot afford early elections because it is too weak and because a majority-assuring electoral law would force it either to perish or to line up with Berlusconi's party, still the strongest within the right of the political spectrum.

Thus, Renzi's announcement provided a foretaste of the dramatic and momentous developments that were to follow in the weeks to come. Both the solemn and widely publicized deal between Renzi and Berlusconi on the electoral law and on a set of limited but relevant constitutional changes (affecting the role of the Senate and the issue of state-regions relations), on 18 January 2014, and the request by the PD that Letta resign on 13 February 2014, to be followed by the subsequent formation of the Renzi Cabinet on 22 February, were key indicators of Renzi's intentions. Indeed, all of his actions suggest that from the start the new Renzi government intended to present itself as what the French call a gouvernement de combat. In other words, the goal was to shake up Italy's stagnation, to reform the political and institutional system (openly defying the M5S on its own turf), and to achieve all of this essentially at any cost (see Newell, this volume). 
This cabinet is expected to be the last before another dissolution of Parliament. Indeed, if Renzi fails, what else can follow but new elections and a new Parliament? While the PD controls only one-third of the members of the Senate, it accounts for almost half of the deputies in the lower chamber. This means that there cannot be a cabinet without its support. But it also means that, like its predecessor, the PD cannot govern without the support of others.

Given the described stalemate of 2013, one could say that at the end of the year there were the very first signs that Italy might start to exit the vicious circle into which it had been plunged. This vicious circle resulted from the fact that the political institutions had proven unable to perform even their minimal functions effectively because there was no feasible parliamentary majority. Voters will be able to create a feasible majority when parliamentary elections are regulated by an appropriate new electoral law. However, the current lack of such a law (and also the absence of a constitutional amendment abolishing the confidence vote of the Senate) would most likely make early elections useless as they would probably reproduce the same hung Parliament that the country already endures. If at least two of the three main parliamentary groups in the Senate do not cooperate to introduce the desperately needed changes described above, any cabinet formed is bound to remain virtually paralyzed; indeed, this is even more likely following the decision by the Constitutional Court to strike down the 2005 law and reintroduce a purely proportional electoral law. The Court's "solution" makes it critical that the political actors find some path forward to adopt a new "majority-assuring" 21 electoral law.

All this may prompt the conclusion that any effort must be pursued to break the described vicious circle and that this can only be done by introducing a new electoral law that would allow future elections to be decisive and, to do so, might hand back the power of dissolution to the president of the Republic and to a president of the Council of Ministers who is willing to use it. The purpose would not necessarily be to dissolve Parliament but rather to enforce much-needed cooperation among and within parties upon which the parliamentary (or fused powers) system relies. The latter point applies in particular to the PD, which has not yet recovered from the aftermath of its disconcerting performance in the presidential election and has divided into factions that are unwilling to fully support even their own leader. But adequate cooperation cannot be expected as long as the very option of dissolution is not, or does not appear to be, available. If and only if the vicious circle is broken will it become possible to pursue all of the structural, political, economic, and social reforms that Italy badly needs and is daily spurred to introduce by both internal and foreign 
opinion leaders and institutions, starting with the European Central Bank and the European Commission. ${ }^{22}$

The goal of achieving critically needed reforms explains why the new PD leadership chose the electoral law as the point of attack against the vicious circle of Italy's paralysis. It also explains Renzi's determination to change the electoral law with whoever proves ready to share this responsibility-including Berlusconi himself. At the same time, it explains the enduring opposition that such a strategy is bound to incur. Finally, it represents the only slim hope to see Italy start effectively going somewhere again at the end of the annus horribilis 2013.

Carlo Fusaro is a Professor of Comparative Public Law at the University of Florence.

Amie Kreppel is a Jean Monnet Chair (ad personam) and the Founding Director of the Jean Monnet Center of Excellence (JMCE) at the University of Florida.

\section{Notes}

1. See A. Bosco and D. McDonnell, "Introduction: The Monti Government and the Downgrade of Italian Parties," in Italian Politics: From Berlusconi to Monti, ed. A. Bosco and D. McDonnell (New York: Berghahn Books, 2012), 37.

2. See A. Di Virgilio and C. M. Radaelli, "Introduction: Technocrats in Office," in Italian Politics: Technocrats in Office, ed. A. Di Virgilio and C. M. Radaelli (New York: Berghahn Books, 2013), 37-57.

3. See Constitutional Court Law No. 1/2014, which was decided on 4 December 2013 and published on 13 January 2014 (Gazzetta Ufficiale, 15 January 2014).

4. If the per capita real disposable income of Italian households in 2013 was down by 2.7 percent compared to 2012, the overall fall since 2007 was an alarming 14 percent. See the chapter by Andrea Brandolini in this volume.

5. The difficulty in forming a new government was certainly not a novelty for Italy; however, after the political revolution of the early 1990s, Italians have become accustomed to a fairly direct and quick link between the outcome of the elections and cabinet formation.

6. As Napolitano put it in his inaugural address to Parliament in joint session on 22 April 2013: "What happened here over the past few days represented the outcome of a long chain of omissions and failures, refusals to cooperate, and irresponsible behaviors." 
7. According to Article 138 of the Italian Constitution, a constitutional law must be voted on twice by each chamber, the second vote no earlier than three months from the first. If the majority is lower than two-thirds, however, a referendum can be called. The proposal had been introduced in the Senate by the Cabinet on 13 June 2013 and was approved on 11 July. It went to the Chamber, where it was passed on 10 September, and was returned to the Senate, where it was approved on 23 October. The Chamber never voted on it the second time.

8. The decision of the Constitutional Court seems to fit into a more general super-activist trend in judicial review for which the way has been paved by Germany's Bundesverfassungsgericht (BVG, Federal Constitutional Court). Over the last three to four years, the BVG has literally been playing cat and mouse with the Bundestag, repeatedly striking down relevant electoral provisions that had been passed by the German parliament. One could argue that the Italian case is taking place in a more general crisis of legitimation suffered by representative democracy.

9. These data stem from our own analysis of information obtained from the website of the Italian Parliament. See http://www.camera.it/leg17/562.

10. See http://www.istat.it/it/lavoro.

11. See http://www.istat.it/it/conti-nazionali.

12. In relation to the effects of the long crisis on the welfare of Italian families, see Brandolini's chapter in this volume.

13. In her chapter in this volume, Daniela Piana places the Berlusconi case within a broader analysis of the complex reciprocal interplay (and interference) that arises in Italy between politics and justice, but also that between media and justice and media and politics.

14. However, there was no forward motion in the economic sphere, as Brandolini's chapter chillingly demonstrates.

15. The Lampedusa tragedies and the difficulty of Italian authorities in dealing with them effectively-in addition to the EU's difficulty in helping some of its more exposed members protect their common borders-also served to focus political and public attention on the issue of immigration.

16. Renzi received the votes of 45.34 percent of the party membership. His main opponent, Gianni Cuperlo, who was backed by most of the old guard (including the former prime minister and the party's strongman, Massimo D’Alema), obtained only 39.4 percent. See http://www.partitodemocratico.it/doc/262717/i-dati-ufficiali-del-voto-degli-iscritti.htm.

17. The total number of votes came to $2,814,881$. Renzi obtained a share of 67.55 percent of valid votes (over 1.8 million), while his two opponents, both MPs, received only 18.21 percent (Cuperlo) and 14.24 percent (Giuseppe Civati). See http://www.partitodemocratico.it/doc/263318/ primarie-pd-2013-risultati-definitivi.htm.

18. See Article 3, which reads as follows: “1. The National Secretary represents the Party, she/he interprets the party line based upon the platform approved when she/he has been elected and is the Party's candidate to the office of President of the Council of Ministers." See http://www. partitodemocratico.it/doc/100454/statuto-del-partito-democratico.htm. 
19. In no less than three points of its decision (Law No. 1/2014), the Court critically and emphatically refers to the "persisting inertia of the legislators."

20. This includes smaller groups, recently established groups, and parts of both larger opposition and majority groups-in other words, all those who do not expect to be a candidate again or, in any instance, do not have a good chance of being re-elected.

21. See M. S. Shugart and M. P. Wattenberg, eds., Mixed-Member Electoral Systems: The Best of Both Worlds? (Oxford: Oxford University Press, 2001), 598.

22. In the same direction of our reasoning, see M. Salvati, "Qualche ragionamento (e una conclusione) sulla crisi,” Il Mulino, no. 1 (2014): 19-20. 